\title{
NANOPARTÍCULAS DE QUITOSANA PARA ENCAPSULAR O VÍRUS DA BRONQUITE INFECCIOSA AVIÁRIA (VBI)
}

\author{
NANOPARTICLES OF CHITOSAN FOR ENCAPSULATING AVIAN INFECTIOUS \\ BRONCHITIS VIRUS (IBV)
}

\author{
P. D. LOPES ${ }^{1 *}$, V. C. MARIGUELA ${ }^{1}$, C. PAVANI ${ }^{1}$, M.L.F. TAMANINI ${ }^{1}$, L. F. DALMOLIN ${ }^{2}$, \\ M. F. S. MONTASSIER ${ }^{1}$, R. F. V. LOPEZ ${ }^{2}$, H. J. MONTASSIER ${ }^{1}$
}

\section{RESUMO}

Em busca de adjuvantes de nova geração para uso na formulação de vacinas contra patógenos virais, o trabalho teve como objetivo preparar nanopartículas de quitosana para encapsular o VBI. Foi utilizado uma suspensão da estirpe H120 atenuada do VBI em líquido córion-alantóide (LCA) para a formulação das nanopartículas por meio da técnica de gelificação iônica. Foram testadas diferentes concentrações de quitosana, ácido acético e tripolifosfato de sódio (TPP) e em diferentes condições de pH. Para o preparo das nanopartículas, um volume da suspensão viral em LCA foi adicionado a 10 volumes da solução de quitosana previamente preparada e, a essa mistura depois de agitada, foram adicionados 5 volumes de TPP, deixando-se essa mistura sob agitação por mais 10 minutos. As nanopartículas foram separadas por duas centrifugações seguidas, sendo armazenado o sobrenadante enquanto que o precipitado, contendo as nanopartcículas foi ressuspendido em PBS. O tamanho das nanopartículas foi medido no aparelho Zetasizer e a eficiência do encapsulamento foi avaliada pela dosagem de proteína presente no sobrenandante através da técnica de Bradford e pela deteç̧ão do RNA genômico viral por RT-PCR. Os resultados demonstraram que as concentrações de quitosana e TPP e o pH influenciaram na geração das nanopartículas, sendo que a melhor formulação foi obtida com a quitosana a $0,2 \%$, o TPP a $0,2 \%$ e em pH 4, o que resultou em uma média de eficiência de encapsulamento da suspensão do VBI de 85\%, e em um tamanho das partículas entre 317 a 378 nanômetros, e confirmando-se o encapsulamento viral pela RT-PCR. Concluindo, as nanopartículas de quitosana preparadas nesse estudo, encapsularam a maior parte dos compontentes antigênicos do VBI presentes na suspensão de LCA, indicando o potencial dessa preparação de nanopartículas para uso como adjuvante/carreador do VBI em novas formulações vacinais para liberação de antígenos via mucosa.

PALAVRAS-CHAVE: ADJUVANTE DE MUCOSA, VACINA DE NOVA GERAÇÃO, VACINA INATIVADA

AGRADECIMENTOS: Conselho Nacional de Desenvolvimento Científico e Tecnológico - CNPq

ÁREA TEMÁTICA: Doenças Infecciosas

\footnotetext{
${ }^{1}$ Faculdade de Ciências Agrárias e Veterinárias da Universidade Estadual Paulista (UNESP) - Câmpus de Jaboticabal

* prisciladiniz_vet@yahoo.com.br

${ }^{2}$ Faculdade de Ciências Farmacêuticas da Universidade de São Paulo - (USP), Câmpus Ribeirão Preto.
} 